Article

\title{
The Effect of Iron Content on Glass Forming Ability and Thermal Stability of $\mathrm{Co}-\mathrm{Fe}-\mathrm{Ni}-\mathrm{Ta}-\mathrm{Nb}-\mathrm{B}-\mathrm{Si}$ Bulk Metallic Glass
}

\author{
Aytekin Hitit * and Hakan Şahin \\ Department of Materials Science and Engineering, Afyon Kocatepe University, Afyonkarahisar 03200, Turkey; \\ hakansahin@aku.edu.tr \\ * Correspondence: hitit@aku.edu.tr; Tel.: +90-272-228-1441
}

Academic Editor: Akihiko Hirata

Received: 23 November 2016; Accepted: 26 December 2016; Published: 29 December 2016

\begin{abstract}
In this study, change in glass forming ability (GFA) and thermal stability of Co-Fe-based bulk metallic glasses were investigated as a function of iron content. Cylindrical samples of alloys with diameters of up to $4 \mathrm{~mm}$ were synthesized by a suction casting method in an arc furnace. Structures and thermal properties of the as-cast samples were determined by $\mathrm{X}$-ray diffraction (XRD) and differential scanning calorimetry (DSC), respectively. It was found that the critical casting thickness of the alloys reduced as iron content was increased and cobalt content was decreased. It was determined that GFA parameters, reduced glass transition temperature $\left(T_{g} / T_{l}\right)$ and $\delta\left(=T_{x} /\left(T_{l}-T_{g}\right)\right)$, show a very good correlation with critical casting thickness values. It was also observed that changing iron content did not effect thermal properties of the alloys.
\end{abstract}

Keywords: metallic glasses; glass forming ability; thermal analysis; microhardness

\section{Introduction}

Co- and Fe-based bulk metallic glasses have received considerable attention because of their good soft magnetic properties [1-10], ultrahigh fracture strength values $[1,3,6,7,9-16]$ and high corrosion resistance $[17,18]$. Besides, they have a potential to be used in biomedical applications $[17,19,20]$. In addition to these attractive properties, they also have very high thermal stability [1-16,21-23]. Additionally, it is known that Co- and Fe-based metallic glasses that contain high amounts of boron can be used as precursors to develop nanocomposites that have ultrahigh hardness values $[8,24,25]$. Because such ultrahigh hardness values of these composites result from the precipitation of borides which form upon devitrification, it is reasonable to expect that, if the boron content of Co- or Fe-based bulk metallic glass is increased, the hardness of the composite becomes higher due to increased volume fraction of borides.

A comparison of boron contents of Co- and Fe-based bulk metallic glasses shows that, in general, boron contents of Co-based bulk metallic glasses $[1,14,15]$ are higher than those of Fe-based bulk metallic glasses $[2,4,6,7,13]$. In fact, the boron content of Co-based bulk metallic glasses can be as high as 37.5 atom \% [14]. However, the highest boron content of a Fe-based bulk metallic glass is 25 atom \% [6]. When compared in terms of cost, it is obvious that Fe-based bulk metallic glasses are more attractive than Co-based bulk metallic glasses. Therefore, replacing cobalt with iron in a Co-based bulk metallic glass containing high amount of boron without degrading its GFA will definitely make the resulting metallic glasses more cost-effective precursors to develop composites having ultrahigh hardness values. In addition, the cost of composites can be lowered further by using low-cost industrial raw materials such as ferro-boron, ferro-niobium, and ferro-tantalum.

In this study, we report the effect of iron content on GFA and the thermal properties of a Co-based bulk metallic glass, $\mathrm{Co}_{41} \mathrm{Fe}_{20} \mathrm{Ni}_{2} \mathrm{Ta}_{2.75} \mathrm{Nb}_{2.75} \mathrm{~B}_{26.5} \mathrm{Si}_{5}$, which has a critical casting thickness of $4 \mathrm{~mm}$ [26]. 
For this reason, cobalt is partially replaced with iron and $\mathrm{Co}_{41-}{ }_{x} \mathrm{Fe}_{20}{ }_{x} \mathrm{Ni}_{2} \mathrm{Ta}_{2.75} \mathrm{Nb}_{2.75} \mathrm{~B}_{26.5} \mathrm{Si}_{5}$ alloys (where $x=10,20$, and 30) were synthesized. The critical casting thicknesses, the thermal properties, and the microhardnesses of the alloys were determined as a function of iron content.

\section{Materials and Methods}

Co-Fe-based alloy ingots with composition of $\mathrm{Co}_{41}-{ }_{x} \mathrm{Fe}_{20+x} \mathrm{Ni}_{2} \mathrm{Ta}_{2.75} \mathrm{Nb}_{2.75} \mathrm{~B}_{26.5} \mathrm{Si}_{5}$ (where $x=10$, $20,30)$ were prepared by arc melting the mixtures of pure Co $(99.8 \mathrm{wt} \%), \mathrm{Fe}(99.9 \mathrm{wt} \%), \mathrm{Ni}(99.9 \mathrm{wt} \%)$, Ta $(99.9 \mathrm{wt} \%), \mathrm{Nb}(99.8 \mathrm{wt} \%)$, and Si $(99.9 \mathrm{wt} \%)$ metals and pure crystalline B (98 wt \%) in a Ti-gettered ultrahigh purity argon atmosphere. Master alloys were melted three times in order to ensure homogeneity. Cylindrical samples of the alloys with diameters up to $4 \mathrm{~mm}$ and a length of $40 \mathrm{~mm}$ were synthesized by suction casting method in a vacuum arc furnace. Structures of the samples were examined by X-ray diffraction (XRD, Shimadzu XRD-6000, Kyoto, Japan) with $\mathrm{Cu}$ K $\alpha$ radiation. The glass transition temperatures $\left(T_{g}\right)$, the crystallization temperatures $\left(T_{x}\right)$, the solidus temperatures $\left(T_{m}\right)$, and the liquidus temperatures $\left(T_{l}\right)$ of the alloys were determined by differential scanning calorimetry (DSC, Netzsch STA 449 F3, Selb, Germany) at a heating rate of $0.33 \mathrm{~K} / \mathrm{s}$. Microhardness measurements were carried out with a Vickers microhardness tester (Shimadzu HMV 2 L, Kyoto, Japan) under a load of $2.94 \mathrm{~N}$. For each alloy, microhardnesses of as-cast samples were measured. Twenty microhardness measurements were carried out for each sample, and the arithmetic mean of the measurements were considered as the microhardness of the alloy.

\section{Results}

XRD patterns of samples are given in Figure 1. The base alloy, $\mathrm{Co}_{41} \mathrm{Fe}_{20} \mathrm{Ni}_{2} \mathrm{Ta}_{2.75} \mathrm{Nb}_{2.75} \mathrm{~B}_{26.5} \mathrm{Si}_{5}$, has a critical casting thickness of $4 \mathrm{~mm}$. For the casting thickness of $5 \mathrm{~mm},(\mathrm{Co}, \mathrm{Fe})_{21} \mathrm{Ta}_{2} \mathrm{~B}_{6}$ and $(\mathrm{Co}, \mathrm{Fe})_{2} \mathrm{~B}$ phases form. The $\mathrm{Co}_{31} \mathrm{Fe}_{30} \mathrm{Ni}_{2} \mathrm{Ta}_{2.75} \mathrm{Nb}_{2.75} \mathrm{~B}_{26.5} \mathrm{Si}_{5}$ alloy has a critical casting thickness of $3 \mathrm{~mm}$. For the casting thickness of $4 \mathrm{~mm}$, the precipitation of $(\mathrm{Co}, \mathrm{Fe})_{2} \mathrm{~B}$ phase was observed for this alloy. The critical casting thicknesses of alloys $\mathrm{Co}_{21} \mathrm{Fe}_{40} \mathrm{Ni}_{2} \mathrm{Ta}_{2.75} \mathrm{Nb}_{2.75} \mathrm{~B}_{26.5} \mathrm{Si}_{5}$ and $\mathrm{Co}_{11} \mathrm{Fe}_{50} \mathrm{Ni}_{2} \mathrm{Ta}_{2.75} \mathrm{Nb}_{2.75} \mathrm{~B}_{26.5} \mathrm{Si}_{5}$ were found to be $2 \mathrm{~mm}$ and $0.5 \mathrm{~mm}$, respectively. For both of these alloys, the precipitation of the $(\mathrm{Co}, \mathrm{Fe})_{2} \mathrm{~B}$, $(\mathrm{Co}, \mathrm{Fe})_{16} \mathrm{Ta}_{6} \mathrm{Si}_{7}$, and $\mathrm{Fe}_{3} \mathrm{Si}$ phases was observed in the samples having diameters larger than the critical casting thicknesses.

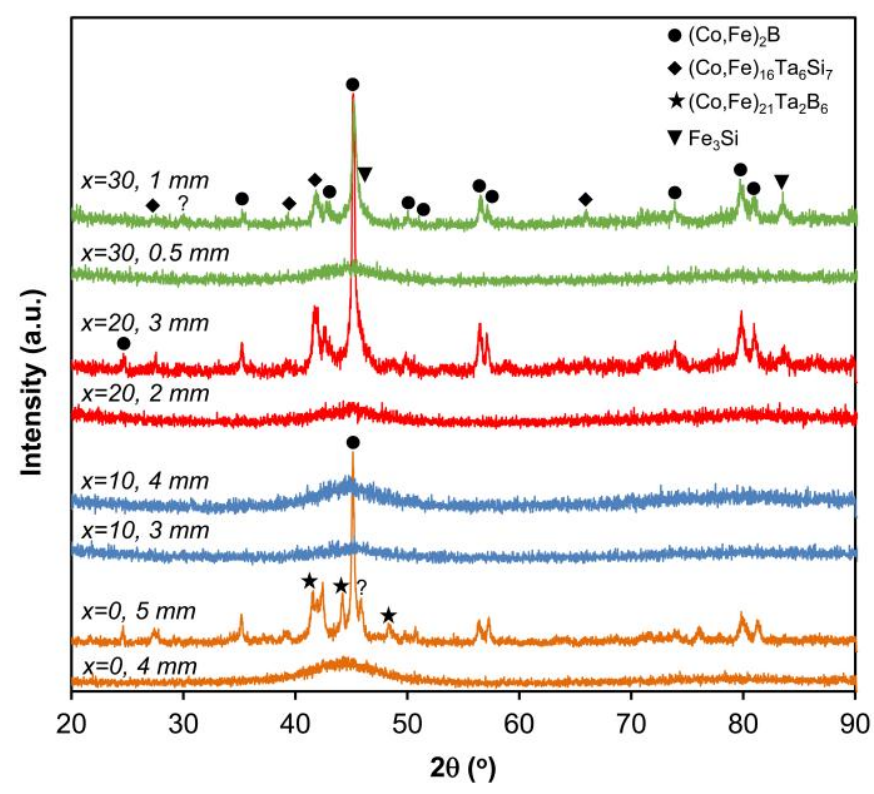

Figure 1. XRD patterns of the $\mathrm{Co}_{41-x} \mathrm{Fe}_{20}{ }_{x} \mathrm{Ni}_{2} \mathrm{Ta}_{2.75} \mathrm{Nb}_{2.75} \mathrm{~B}_{26.5} \mathrm{Si}_{5}(x=10,20$, and 30) alloys. 
Thermal properties of the alloys were determined by DSC (Figure 2). During heating, all the DSC traces showed an endothermic event, which is the indication of the glass transition and followed by exothermic reactions, which are the signs of crystallization of the glassy structure. $T_{g}$ and $T_{x}$ of the base alloy, $\mathrm{Co}_{41} \mathrm{Fe}_{20} \mathrm{Ni}_{2} \mathrm{Ta}_{2.75} \mathrm{Nb}_{2.75} \mathrm{~B}_{26.5} \mathrm{Si}_{5}$, are 891 and $947 \mathrm{~K}$, respectively [21]. The $T_{g}$ of $\mathrm{Co}_{31} \mathrm{Fe}_{30} \mathrm{Ni}_{2} \mathrm{Ta}_{2.75} \mathrm{Nb}_{2.75} \mathrm{~B}_{26.5} \mathrm{Si}_{5}$ alloy is $890 \mathrm{~K}$. Additionally, the $T_{x}$ of $\mathrm{Co}_{31} \mathrm{Fe}_{30} \mathrm{Ni}_{2} \mathrm{Ta}_{2.75} \mathrm{Nb}_{2.75} \mathrm{~B}_{26.5} \mathrm{Si}_{5}$ alloy is $957 \mathrm{~K}$, which is about $10 \mathrm{~K}$ higher than the $T_{x}$ of $\mathrm{Co}_{41} \mathrm{Fe}_{20} \mathrm{Ni}_{2} \mathrm{Ta}_{2.75} \mathrm{Nb}_{2.75} \mathrm{~B}_{26.5} \mathrm{Si}_{5}$ alloy. The $T_{g}$ of $\mathrm{Co}_{21} \mathrm{Fe}_{40} \mathrm{Ni}_{2} \mathrm{Ta}_{2.75} \mathrm{Nb}_{2.75} \mathrm{~B}_{26.5} \mathrm{Si}_{5}$ and $\mathrm{Co}_{11} \mathrm{Fe}_{50} \mathrm{Ni}_{2} \mathrm{Ta}_{2.75} \mathrm{Nb}_{2.75} \mathrm{~B}_{26.5} \mathrm{Si}_{5}$ alloys are found to be 895 and $894 \mathrm{~K}$, respectively. Moreover, the $T_{x}$ of $\mathrm{Co}_{21} \mathrm{Fe}_{40} \mathrm{Ni}_{2} \mathrm{Ta}_{2.75} \mathrm{Nb}_{2.75} \mathrm{~B}_{26.5} \mathrm{Si}_{5}$ and $\mathrm{Co}_{11} \mathrm{Fe}_{50} \mathrm{Ni}_{2}$ $\mathrm{Ta}_{2.75} \mathrm{Nb}_{2.75} \mathrm{~B}_{26.5} \mathrm{Si}_{5}$ alloys are determined as 960 and $964 \mathrm{~K}$, respectively. In addition, the $T_{l}$ of the base alloy is $1443 \mathrm{~K}$ [26], and the $T_{l}$ of 30,40, and 50 atom \% iron-containing alloys are 1458, 1488, and 1532 $\mathrm{K}$, respectively. Thermal properties of the alloys are given in Table 1 . In addition, the microhardnesses of the alloys were determined to be around $1200 \mathrm{H}_{\mathrm{v}}$.
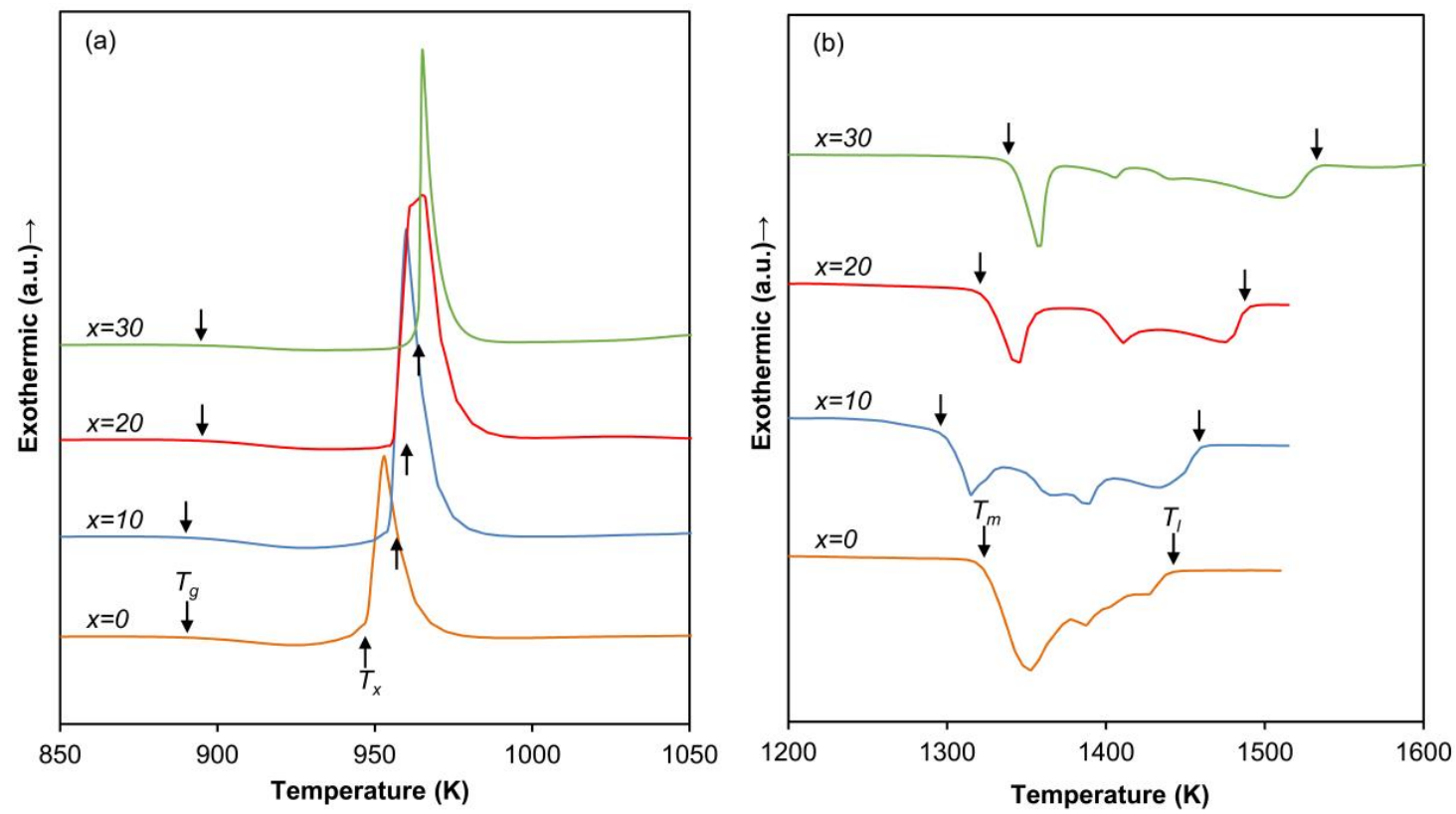

Figure 2. DSC curves of the $\mathrm{Co}_{41}{ }_{x} \mathrm{Fe}_{20}+{ }_{x} \mathrm{Ni}_{2} \mathrm{Ta}_{2.75} \mathrm{Nb}_{2.75} \mathrm{~B}_{26.5} \mathrm{Si}_{5}(x=10,20$ and 30) alloys. (a) low temperature; (b) high temperature.

Table 1. Thermal properties $\left(T_{g}, T_{x}, T_{l}, T_{m}\right)$, parameters for GFA, critical casting thickness and microhardnesses of $\mathrm{Co}-\mathrm{Fe}-\mathrm{Ni}-\mathrm{Ta}-\mathrm{Nb}-\mathrm{B}-\mathrm{Si}$ alloys.

\begin{tabular}{cccccccccc}
\hline Alloy & $T_{g}(\mathbf{K})$ & $T_{x}(\mathbf{K})$ & $T_{m}(\mathbf{K})$ & $T_{l}(\mathbf{K})$ & $T_{g} / T_{l}$ & $\begin{array}{c}T_{x} / \\
\left(T_{l}-T_{g}\right)\end{array}$ & $\begin{array}{c}T_{x} l \\
\left(T_{g}+T_{l}\right)\end{array}$ & $\begin{array}{c}D_{\max } \\
(\mathbf{m m})\end{array}$ & $\boldsymbol{H}_{\boldsymbol{v}}$ \\
\hline $\mathrm{Co}_{41} \mathrm{Fe}_{20} \mathrm{Ni}_{2} \mathrm{Ta}_{2.75} \mathrm{Nb}_{2.75} \mathrm{~B}_{26.5} \mathrm{Si}_{5}[26]$ & 891 & 947 & 1323 & 1443 & 0.617 & 1.716 & 0.406 & 4 & 1197 \\
$\mathrm{Co}_{31} \mathrm{Fe}_{30} \mathrm{Ni}_{2} \mathrm{Ta}_{2.75} \mathrm{Nb}_{2.75} \mathrm{~B}_{26.5} \mathrm{Si}_{5}$ & 890 & 957 & 1295 & 1458 & 0.610 & 1.685 & 0.408 & 3 & 1242 \\
$\mathrm{Co}_{21} \mathrm{Fe}_{40} \mathrm{Ni}_{2} \mathrm{Ta}_{2.75} \mathrm{Nb}_{2.75} \mathrm{~B}_{26.5} \mathrm{Si}_{5}$ & 895 & 960 & 1318 & 1488 & 0.601 & 1.619 & 0.403 & 2 & 1240 \\
$\mathrm{Co}_{11} \mathrm{Fe}_{50} \mathrm{Ni}_{2} \mathrm{Ta}_{2.75} \mathrm{Nb}_{2.75} \mathrm{~B}_{26.5} \mathrm{Si}_{5}$ & 894 & 964 & 1343 & 1532 & 0.584 & 1.511 & 0.397 & 0.5 & 1238 \\
\hline
\end{tabular}

\section{Discussion}

The critical casting thickness decreases as iron content is increased. It is quite obvious that the reduction in critical casting thickness results from the fact that the $T_{l}$ of the alloys increases with iron content. For a constant $T_{g}$, if liquidus temperature increases, the minimum cooling rate necessary to obtain a completely amorphous structure also increases. As a result, the casting thickness must be decreased to achieve this cooling rate. Well-known GFA parameters, reduced glass transition temperature $\left(T_{g} / T_{l}\right)[27]$ and $\delta\left(=T_{x} /\left(T_{l}-T_{g}\right)\right)$, show a very good correlation with the critical casting 
thickness values (Figure 3). However, the correlation between the GFA parameter $T_{x} /\left(T_{g}+T_{l}\right)$ and the critical casting thickness values is not as satisfactory as those of the others.
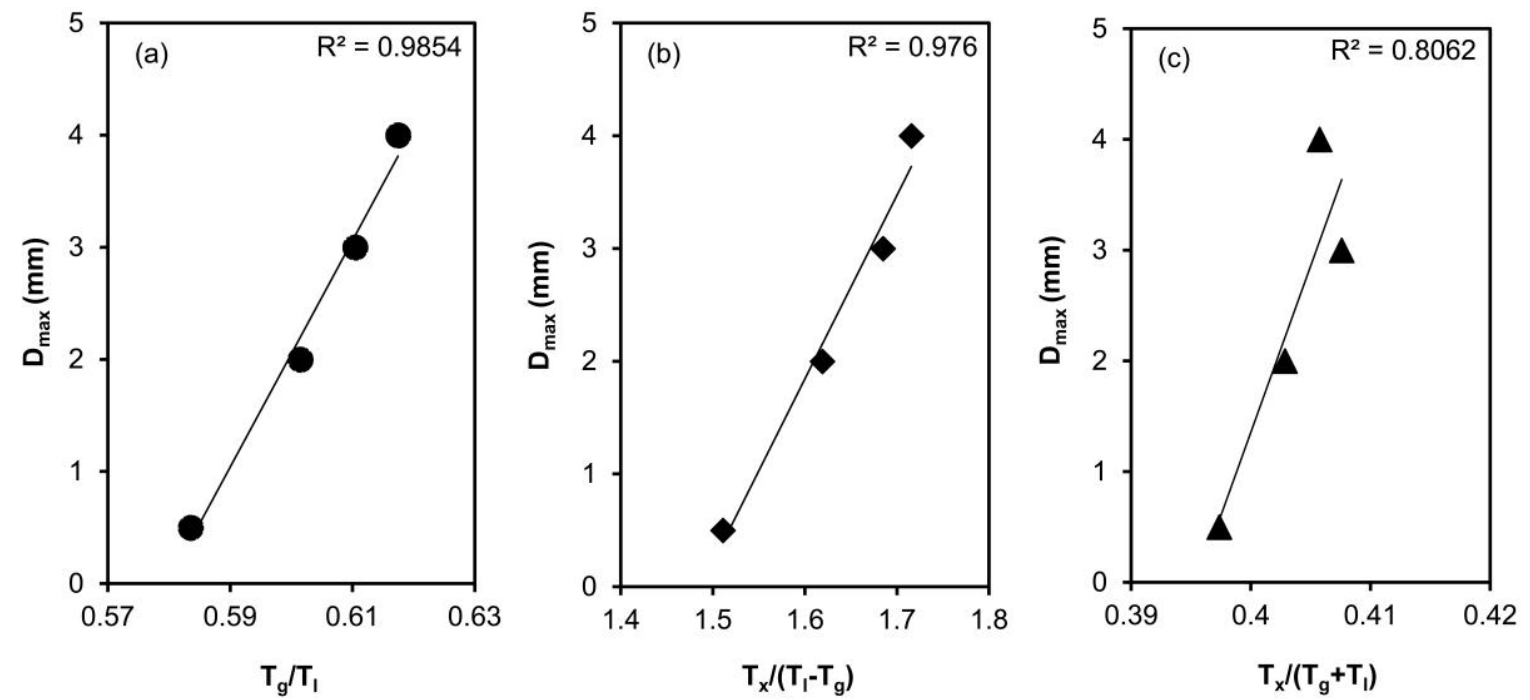

Figure 3. Relationship between the critical casting thickness $\left(D_{\max }\right)$ for the formation of a glassy phase and GFA parameters. (a) Reduced glass transition temperature $\left(T_{g} / T_{l}\right) ;(\mathbf{b}) T_{x} /\left(T_{l}-T_{g}\right) ;(\mathbf{c}) T_{x} /\left(T_{g}+T_{l}\right)$.

$(\mathrm{Co}, \mathrm{Fe})_{2} \mathrm{~B},(\mathrm{Co}, \mathrm{Fe})_{16} \mathrm{Ta}_{6} \mathrm{Si}_{7}$, and $\mathrm{Fe}_{3} \mathrm{Si}$ phases form during cooling. It is shown that $(\mathrm{Co}, \mathrm{Fe})_{2} \mathrm{~B}$ phase forms at temperatures higher than temperatures at which the $(\mathrm{Co}, \mathrm{Fe})_{16} \mathrm{Ta}_{6} \mathrm{Si}_{7}$ phase forms [25]. In other words, $(\mathrm{Co}, \mathrm{Fe})_{2} \mathrm{~B}$ is the first phase that precipitates during cooling. Since the melting temperature of the $\mathrm{Fe}_{2} \mathrm{~B}$ phase is higher than the $\mathrm{Co}_{2} \mathrm{~B}$ phase, increasing iron content increases the melting temperature of the $(\mathrm{Co}, \mathrm{Fe})_{2} \mathrm{~B}$ phase. As a result, the liquidus temperatures of the alloys increase.

Glass transition temperatures of the alloys do not change with iron content. However, crystallization temperatures increase slightly. Similarly, microhardnesses of the alloys remain almost constant. Cohesive energies of $\mathrm{Fe}-\mathrm{Fe}$ and $\mathrm{Co}-\mathrm{Co}$ bonds are 413 and $424 \mathrm{~kJ} / \mathrm{mol}$, respectively [28]. It is quite reasonable to assume that cohesive energy of $\mathrm{Fe}-\mathrm{Co}$ bond is close to these values. When the iron content of the alloys is increased, the number of $\mathrm{Co}-\mathrm{Co}$ bonds decreases, but the number of $\mathrm{Fe}-\mathrm{Co}$ bonds increases. Since cohesive energies of these bond are almost the same, the total cohesive energy of the amorphous structure remains constant. For this reason, the thermal properties and the microhardnesses of the alloys do not change.

The $\mathrm{Co}_{21} \mathrm{Fe}_{40} \mathrm{Ni}_{2} \mathrm{Ta}_{2.75} \mathrm{Nb}_{2.75} \mathrm{~B}_{26.5} \mathrm{Si}_{5}$ alloy has a reasonably high iron content and critical casting thickness. Therefore, it is believed that it can used as a precursor to develop composites with ultrahigh hardness values at a low cost.

\section{Conclusions}

The following conclusions can be reached from this study:

1. The critical casting thicknesses of the alloys decrease with iron content due to the increase in liquidus temperatures.

2. The critical casting thicknesses of the alloys show a very good correlation with reduced glass transition temperature, $T_{g} / T_{l}$ and $T_{x} /\left(T_{l}-T_{g}\right)$.

3. Thermal properties and microhardnesses of the alloys do not change with iron content because of the fact that cohesive energies of the $\mathrm{Co}-\mathrm{Co}-$ and $\mathrm{Fe}-\mathrm{Fe}$ bonds are almost the same.

Acknowledgments: This study was supported by grant No. 10.MUH.10 from the Research Council of Afyon Kocatepe University. 
Author Contributions: Aytekin Hitit and Hakan Şahin synthesized the alloys and cast the samples. Hakan Şahin performed XRD and DSC experiments and microhardness measurements. Aytekin Hitit and Hakan Şahin analyzed the results. Aytekin Hitit wrote and edited the paper.

Conflicts of Interest: The authors declare no conflict of interest.

\section{References}

1. Inoue, A.; Shen, B.L.; Koshiba, H.; Kato, H.; Yavari, A.R. Ultra-high strength above $5000 \mathrm{MPa}$ and soft magnetic properties of Co-Fe-Ta-B bulk glassy alloys. Acta Mater. 2004, 52, 1631-1637. [CrossRef]

2. Liu, D.Y.; Sun, W.S.; Zhang, H.F.; Hu, Z.Q. Preparation, thermal stability and magnetic properties of Fe-Co-Ni-Zr-Mo-B bulk metallic glass. Intermetallic 2004, 12, 1149-1152. [CrossRef]

3. Song, D.S.; Kim, J.H.; Fleury, E.; Kim, W.T.; Kim, D.H. Synthesis of ferromagnetic Fe-based bulk glassy alloys in the Fe-Nb-B-Y system. J. Alloy. Compd. 2005, 389, 159-164. [CrossRef]

4. Lee, S.; Kato, H.; Kubota, T.; Yubuta, K.; Makino, A.; Inoue, A. Excellent Thermal Stability and Bulk Glass Forming Ability of Fe-B-Nb-Y Soft Magnetic Metallic Glass. Trans. Jpn. Inst. Met. 2008, 49, 506-512. [CrossRef]

5. Tiberto, P.; Piccin, R.; Lupu, N.; Chiriac, H.; Baricco, M. Magnetic properties of Fe-Co-based bulk metallic glasses. J. Alloy. Compd. 2009, 483, 608-612. [CrossRef]

6. Jia, F.; Zhang, W.; Zhang, X.; Xie, G.; Kimura, H.; Makino, A.; Inoue, A. Effect of Co concentration on thermal stability and magnetic properties of (Fe,Co)-Nb-Gd-B glassy alloys. J. Alloy. Compd. 2010, 504S, 129-131. [CrossRef]

7. Dong, Y.; Wang, A.; Man, Q.; Shen, B. $\left(\mathrm{Co}_{1-x} \mathrm{Fe}_{x}\right)_{68} \mathrm{~B}_{21.9} \mathrm{Si}_{5.1} \mathrm{Nb}_{5}$ bulk glassy alloys with high glass-forming ability, excellent soft-magnetic properties and super high fracture strength. Intermetallics 2012, 23, 63-67. [CrossRef]

8. Han, J.J.; Wang, C.; Kou, S.; Liu, X. Thermal stability, crystallization behavior, Vickers hardness and magnetic properties of $\mathrm{Fe}-\mathrm{Co}-\mathrm{Ni}-\mathrm{Cr}-\mathrm{Mo}-\mathrm{C}-\mathrm{B}-\mathrm{Y}$ bulk metallic glasses. Trans. Nonferr. Met. Soc. China 2013, 23, 148-155. [CrossRef]

9. Li, J.W.; He, A.N.; Shen, B.L. Effect of Tb addition on the thermal stability, glass-forming ability and magnetic properties of Fe-B-Si-Nb bulk metallic glass. J. Alloy. Compd. 2014, 586, 46-49. [CrossRef]

10. Li, J.W.; Estevez, D.; Jiang, K.M.; Yang, W.M.; Man, Q.K.; Chang, C.T.; Wang, X.M. Electronic-structure origin of the glass-forming ability and magnetic properties in Fe-RE-B-Nb bulk metallic glasses. J. Alloy. Compd. 2014, 617, 332-336. [CrossRef]

11. Inoue, A.; Shen, B.L.; Chang, C.T. Super-high strength of over $4000 \mathrm{MPa}$ for Fe-based bulk glassy alloys in $\left[\left(\mathrm{Fe}_{1-x} \mathrm{Co}_{x}\right)_{0.75} \mathrm{~B}_{0.2} \mathrm{Si}_{0.05}\right]_{96} \mathrm{Nb}_{4}$ system. Acta Mater. 2004, 52, 4093-4099. [CrossRef]

12. Inoue, A.; Shen, B.L.; Chang, C.T. Fe- and Co-based bulk glassy alloys with ultrahigh strength of over $4000 \mathrm{MPa}$. Intermetallics 2006, 14, 936-944. [CrossRef]

13. Chang, Z.Y.; Huang, X.M.; Chen, L.Y.; Ge, M.Y.; Jiang, Q.K.; Nie, X.P.; Jiang, J.Z. Catching Fe-based bulk metallic glass with combination of high glass forming ability, ultrahigh strength and good plasticity in Fe-Co-Nb-B system. Mater. Sci. Eng. A 2009, 517, 246-248. [CrossRef]

14. Dun, C.; Liu, H.; Shen, B. Enhancement of plasticity in $\mathrm{Co}-\mathrm{Nb}-\mathrm{B}$ ternary bulk metallic glasses with ultrahigh strength. J. Non Cryst. Solids 2012, 358, 3060-3064. [CrossRef]

15. Wang, J.; Wang, L.; Guan, S.; Zhu, S.; Li, R.; Zhang, T. Effects of boron content on the glass-forming ability and mechanical properties of Co-B-Ta glassy alloys. J. Alloy. Compd. 2014, 617, 7-11. [CrossRef]

16. Yazici, Z.Ö.; Hitit, A.; Yalcin, Y.; Ozgul, M. Effects of Minor Cu and Si Additions on Glass Forming Ability and Mechanical Properties of Co-Fe-Ta-B Bulk Metallic Glass. Met. Mater. Int. 2016, 22, 50-57. [CrossRef]

17. Li, S.; Wei, Q.; Li, Q.; Jiang, B.; Chen, Y.; Sun, Y. Development of Fe-based bulk metallic glasses as potential biomaterials. Mater. Sci. Eng. C 2015, 52, 235-241. [CrossRef] [PubMed]

18. Souza, C.A.C.; Ribeiro, D.V.; Kiminami, C.S. Corrosion resistance of Fe-Cr-based amorphous alloys: An overview. J. Non Cryst. Solids 2016, 442, 56-66. [CrossRef]

19. Zhou, Z.; Wei, Q.; Li, Q.; Jiang, B.; Chen, Y.; Sun, Y. Development of Co-based bulk metallic glasses as potential biomaterials. Mater. Sci. Eng. C 2016, 69, 46-51. [CrossRef] [PubMed]

20. Li, H.F.; Zheng, Y.F. Recent advances in bulk metallic glasses for biomedical applications. Acta Biomater. 2016, 36, 1-20. [CrossRef] [PubMed] 
21. Men, H.; Pang, S.J.; Zhang, T. Thermal stability and microhardness of new Co-based bulk metallic glasses. Mater. Sci. Eng. A 2007, 449-451, 538-540. [CrossRef]

22. Hitit, A.; Talaş, Ş.; Kara, R. Effects of silicon and chromium additions on glass forming ability and microhardness of Co-based bulk metallic glasses. Indian J. Eng. Mater. Sci. 2014, 21, 111-115.

23. Li, J.; Law, J.Y.; Ma, H.; He, A.; Man, Q.; Men, H.; Huo, J.; Chang, C.; Wang, X.; Li, R.W. Magnetocaloric effect in Fe-Tm-B-Nb metallic glasses near room temperature. J. Non Cryst. Solids 2015, 425, 114-117. [CrossRef]

24. Fornell, J.; González, S.; Rossinyol, E.; Suriñach, S.; Baro, M.D.; Louzguine-Luzgin, D.V.; Perepezko, J.H.; Sort, J.; Inoue, A. Enhanced mechanical properties due to structural changes induced by devitrification in Fe-Co-B-Si-Nb bulk metallic glass. Acta Mater. 2010, 58, 6256-6266. [CrossRef]

25. Hitit, A.; Geçgin, M.; Öztürk, P. Effect of Annealing on Microstructure and Microhardness of Co-Fe-Ni-Ta-B-Si Bulk Metallic Glass. J. Mater. Sci. Technol. 2015, 31, 148-152. [CrossRef]

26. Çolak, F. Synthesis and Characterization of Nickel, Silicon and Niobium Containing Cobalt-Iron Based Bulk Metallic Glasses. Ph.D. Thesis, Afyon Kocatepe University, Afyonkarahisar, Turkey, 2011.

27. Turnbull, D. Under What Conditions can a Glass be Formed? Contemp. Phys. 1969, 10, 473-478. [CrossRef]

28. Kittel, C. Energy Bands. In Introduction to Solid State Physics, 8th ed.; Stuart, C., Patricia, M.F., Martin, B., Eds.; John Wiley and Sons, Inc.: Hoboken, NJ, USA, 2005; Volume 7, pp. 161-182.

(C) 2016 by the authors; licensee MDPI, Basel, Switzerland. This article is an open access article distributed under the terms and conditions of the Creative Commons Attribution (CC-BY) license (http://creativecommons.org/licenses/by/4.0/). 